\title{
Pulmonary hypertension in hemolytic anemias
}

\section{Shannon Wahl* and Elliott Vichinsky}

\author{
Address: Department of Hematology/Oncology, Children's Hospital and Research Center Oakland, 747 52nd Street, Oakland, CA 94609, USA \\ *Corresponding author: Shannon Wahl (swahl@mail.cho.org) \\ Fl000 Medicine Reports 2010, 2:10 (doi:10.3410/M2-10)
}

The electronic version of this article is the complete one and can be found at: http://fl000.com/reports/medicine/content/2/10

\begin{abstract}
Pulmonary hypertension (PH) has been reported with nearly all forms of the inherited as well as the acquired hemolytic anemias. Recent research investigating the pathophysiology of $\mathrm{PH}$ in sickle cell disease and thalassemia has helped elucidate the central role of hemolysis-mediated endothelial dysfunction in the development of $\mathrm{PH}$ in these populations. Although the most appropriate treatment of $\mathrm{PH}$ in patients with hemolytic anemia is not clearly defined, the associated significant increased risk of death underscores the need for randomized clinical trials in this area.
\end{abstract}

\section{Introduction and context}

Pulmonary hypertension (PH) is a syndrome of restricted blood flow through the pulmonary arterial circulation associated with increased pulmonary vascular resistance and elevated pulmonary artery pressures. While there are case reports of this syndrome occurring in most hemolytic anemias, including hereditary spherocytosis, pyruvate kinase deficiency, unstable hemoglobin variants, paroxysmal nocturnal hemoglobinuria, and microangiopathic hemolytic anemias [1-6], data from larger cohorts have been reported only in sickle cell disease (SCD) and thalassemia and will be the focus of this report. The gold standard for diagnosis of $\mathrm{PH}$ is elevated mean pulmonary artery pressure (mPAP) of $\geq 25 \mathrm{mmHg}$ measured during right heart catheterization. Echocardiography can be used as a noninvasive method to estimate pulmonary pressures by measuring the tricuspid regurgitant jet velocity (TRV). A TRV of $\geq 2.5 \mathrm{~m} / \mathrm{s}$ has been validated as a reliable predictor of elevated pulmonary artery pressures in idiopathic $\mathrm{PH}$ [7] and has also been shown to correlate well with mPAP measured during catheterization in adult SCD patients [8]. Recent research has helped define the link between hemolysis and the development of pulmonary hypertension, establish the prevalence and risk factors for its development and, perhaps most importantly, identify $\mathrm{PH}$ as a significant marker for death.

\section{Recent advances \\ Pathophysiology}

While the initial mechanism of injury in various forms of PH may vary, the end result is a range of endothelial damage seen on histopathology, including hyperplasia, proliferation, thrombosis in situ, and finally irreversible plexiform arteriopathy [7]. The pathways that lead to this injury as a result of hemolysis are multifactorial and involve nitric oxide depletion and reduced bioavailability, dysregulation of arginine metabolism, oxidative stress, and a hypercoagulable state. Nitric oxide (NO), synthesized from arginine by endothelial nitric oxide synthase, plays a critical role in maintaining vascular homeostasis. Not only does NO maintain vasodilation by activating cGMP-dependent protein kinases, but it also inhibits platelet aggregation and attachment, limits ischemia-reperfusion injury and down-regulates adhesion molecules such as vascular cell adhesion molecule, selectins, and the potent vasoconstrictor endothelin-1 [9]. During hemolysis, breakdown of the erythrocyte releases hemoglobin and the enzyme arginase into circulation. Cell-free hemoglobin has been shown to be a potent scavenger of NO, effectively preventing these vasoprotective properties [10]. In addition, arginase depletes the substrate for NO synthesis by conversion of arginine to ornithine, compounding the state of reduced NO bioavailability. The downstream products 
of this shift in amino acid metabolism to ornithine include proline and polyamines, metabolites known to increase vascular smooth muscle proliferation and collagen production and deposition, respectively [11]. Collectively, these changes result in vasoconstriction and vascular remodeling of the pulmonary vascular endothelium. The relationship between hemolysis, NO depletion, arginine metabolism dysregulation, and $\mathrm{PH}$ has been demonstrated in animal models as well as in vitro and in vivo experiments over the past few years. Multiple studies in adults as well as children with SCD have identified a strong link between the intensity of hemolysis and development of $\mathrm{PH}[8,12,13]$. Mouse models of SCD as well as alloimmune hemolytic anemia with intravascular hemolysis have been shown to develop PH [14]. Canine modes of intravascular hemolysis also demonstrate induction of $\mathrm{PH}$ that is partially reversed by administration of NO [15]. Reiter et al. [10] showed that plasma from SCD patients consumes $\mathrm{NO}$ and the inactivation of $\mathrm{NO}$ is directly proportional to the hemolytic rate. Arginase activity has also been shown to correlate with the hemolytic rate and a low arginine to ornithine ratio reflecting the dysregulation of arginine metabolism has been found in thalassemia and SCD. In patients with SCD, this ratio correlates significantly with PH [11].

The oxidative damage that occurs with chronic hemolysis also likely contributes to the development of $\mathrm{PH}$. Reduced glutathione is a critical antioxidant and its depletion has recently been shown to correlate with hemolysis and was independently associated with $\mathrm{PH}$ in SCD patients [16]. Finally, the hypercoagulable state associated with SCD and thalassemia has been shown to contribute to the development of PH through a series of recent experiments. Villagra et al. [17] showed the correlation between platelet activation, markers of hemolysis, and severity of PH in SCD. Kuypers [18] has demonstrated the procoagulant nature of the abnormal erythrocyte membrane that occurs with oxidative damage in hemolytic anemias. Setty et al. [19] has reported increased tissue factor expression and thrombin generation induced by free heme. Splenectomy contributes to this hypercoagulable state and is a known risk factor for PH in thalassemia [20]. Singer et al. [21] have reported an association between $\mathrm{PH}$ and platelet activation, hypercoagulability, and splenectomy in patients with thalassemia.

In summary, the development of PH due to hemolysis is multifactorial and involves NO deficiency, dysregulated arginine metabolism, oxidative stress, and hypercoagulability. Although the chronology of the vascular injury that leads to PH is not completely defined, there is likely some initial vasoconstriction and proliferative vasculopathy that progresses to irreversible luminal narrowing with vascular remodeling over time (Figure 1).

\section{Prevalence}

Multiple prospective screening studies have found roughly a third of adult patients with SCD have PH as

Figure I. Progression of pulmonary hypertension in sickle cell disease and thalassemia

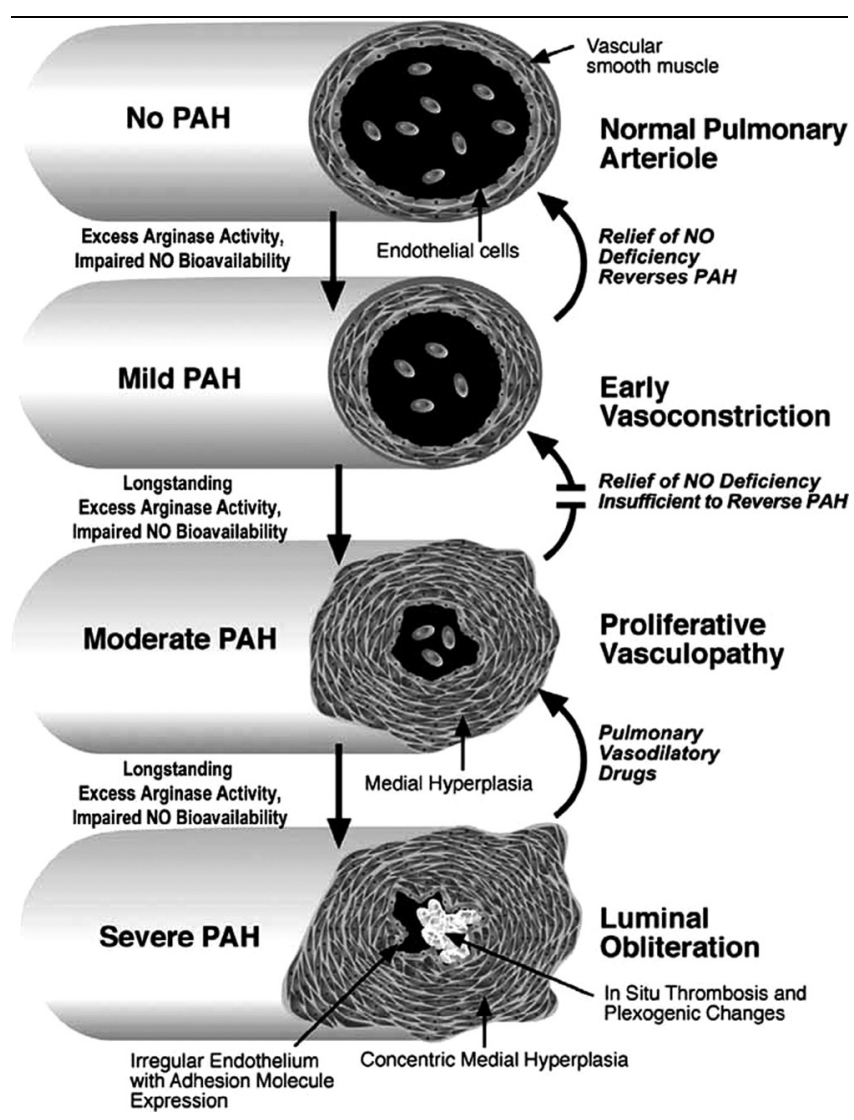

In this hypothetical model, impaired nitric oxide (NO) bioavailability that results from chronic hemolysis and oxidative stress triggers chronic pulmonary vasoconstriction, mildly elevating pulmonary vascular resistance and pulmonary artery pressures. Excess arginase liberated from the erythrocyte during hemolysis consumes arginine, the obligate substrate for NO production, and creates a shift towards ornithine production that contributes to collagen deposition and vascular smooth muscle proliferation. Overabundant thrombin generation contributes to a chronic hypercoagulable state, increases arginase activity, and stimulates polyamine synthesis in vascular smooth muscle cells. As this becomes more longstanding, vascular smooth muscle hyperplasia begins to create a relatively fixed lesion, compounded in later stages by irregular, activated endothelium with expression of adhesion molecules. In situ thrombosis further occludes the vessel lumen, and results in plexogenic changes, further accelerating the progression of the pulmonary artery hypertension (PAH). Figure and caption reproduced with permission from [13]. Copyright (C) 2007 Informa Healthcare. 
defined by a TRV of $\geq 2.5 \mathrm{~m} / \mathrm{s}$ and approximately $10 \%$ have severe PH (TRV of $>3 \mathrm{~m} / \mathrm{s}$ ) $[8,22-24]$. Most reports of $\mathrm{PH}$ in pediatric SCD patients have also found a prevalence of $30 \%$, although most of these are retrospective and therefore associated with some selection bias due to screening of symptomatic patients [25-27]. A recent study of children with SCD prospectively screened with echocardiography reported $\mathrm{PH}$ in $11 \%$ of 290 patients [28].

Studies of $\mathrm{PH}$ in thalassemia patients report less consistent results with a prevalence range of 10-75\% depending on age, transfusion regimen, and degree of left ventricular dysfunction. Thalassemia major (TM) patients have a more clinically severe anemia and are typically transfusion dependent very early in life whereas thalassemia intermedia (TI) patients have a later onset of symptoms and may be less frequently transfused. Transfusions appear to have a preventative effect as $\mathrm{PH}$ is more frequently reported with TI compared to regularly transfused TM patients. Aessopos et al. [29] compared 131 transfused TM and 74 non-transfused TI patients and found $\mathrm{PH}$ in $23 \%$ of TI patients and no $\mathrm{PH}$ in the TM cohort. Singer et al. [21] reported PH in 10 of 18 transfused TM and 7 of 7 TI patients. Others have found $\mathrm{PH}$ in $44 \%$ of 36 [30] and $9.8 \%$ of 368 [31] regularly transfused TM patients.

\section{Amino-terminal pro-brain natriuretic peptide}

High levels of brain natriuretic peptide (BNP) reflect cardiac volume and pressure afterload as this hormone is released in response to cardiomyocyte stretching. The proBNP hormone is cleaved into the biologically active BNP and an easily measurable inactive amino-terminal proBNP. The amino-terminal proBNP level has been shown to correlate with severity of pulmonary artery pressure elevation and right ventricular dysfunction in primary PH [7]. It has more recently been validated as a biomarker for PH in SCD. Machado et al. [24] found that amino-terminal proBNP levels were higher in SCD patients with $\mathrm{PH}$ and correlated directly with TRV ( $\mathrm{R}=0.5, P<0.001)$. A level of $160 \mathrm{pg} / \mathrm{ml}$ or greater had $78 \%$ positive predictive value for the diagnosis of $\mathrm{PH}$ in this cohort. Importantly, they also found this level was an independent predictor of mortality (relative risk for death 5.1; 95\% confidence interval 2.1-12.5; $P<0.001$ ).

\section{Risk of mortality}

Heart failure is the most common cause of death in thalassemia [32]. While this is commonly due to left ventricular dysfunction resulting from transfusioninduced iron overload, right heart failure is now increasingly recognized [33]. Long-term longitudinal studies of thalassemia patients are needed to further delineate the contribution of $\mathrm{PH}$ to mortality in this population.

Gladwin et al. [8] identified PH as a significant risk factor for death in adults with SCD. In a cohort of 195 patients, the rate ratio for death was 10.1 for those with TRV >2.5 $\mathrm{m} / \mathrm{s}$ at a mean follow up of 18 months (Figure 2). This significantly increased risk of death has been validated in multiple other studies [22-24]. In a recent report of 88 children, all 18 patients with $\mathrm{PH}$ were alive at a mean follow-up period of 3 years [34], suggesting there may be some progressive damage over time that ultimately leads to death in adulthood. It is important to note that this increased mortality is seen despite the fact that the mPAPs in hemolytic anemias are much lower than those reported with idiopathic $\mathrm{PH}$. It remains unclear if $\mathrm{PH}$ is the direct cause of death or simply a marker of severe vasculopathy in SCD. PH has been reported as a frequent finding in autopsies of SCD patients with sudden death [35] and vaso-occlusive pain crisis is known to commonly precede sudden death in these patients. Recent work by Machado et al. [36] may shed light on the pathophysiology of sudden death with the finding that, during crisis, there is worsening of hemolysis as measured by hemoglobin and lactate dehydrogenase and also worsening of PH as measured by TRV. They have speculated that acute worsening of $\mathrm{PH}$ during crisis in patients who are already at the limits of cardiopulmonary compensation could potentially result in either dysrhythmia or acute right ventricular failure. More research is needed to further investigate these results and clarify the cause and effect relationship of $\mathrm{PH}$ and death in patients with hemolytic anemia.

\section{Implications for clinical practice}

Patients with hemolytic anemia and $\mathrm{PH}$ may be asymptomatic or only mildly symptomatic. Even if dyspnea on exertion or other symptoms develop, these may be misinterpreted as either deconditioning or simply due to chronic anemia. Therefore, clinicians must maintain an index of suspicion and screen patients with echocardiography. There are ongoing clinical trials evaluating the most appropriate treatment strategies for hemolysis-associated $\mathrm{PH}$, although definitive treatment guidelines have not been fully established. The findings that regular transfusions may prevent or slow the progression of $\mathrm{PH}$ in thalassemia $[37,38]$ suggest a trial of aggressive transfusion therapy is appropriate for these patients. The known association of $\mathrm{PH}$ with hypercoagulability, especially after splenectomy, in thalassemia suggests preventative anticoagulation is warranted, although there are no data to clarify if antiplatelet or antithrombotic agents are more beneficial. Because of the high prevalence of $\mathrm{PH}$ after splenectomy in $\mathrm{TI}$, the 
Figure 2. Kaplan-Meier survival curves according to the tricuspid regurgitant jet velocity

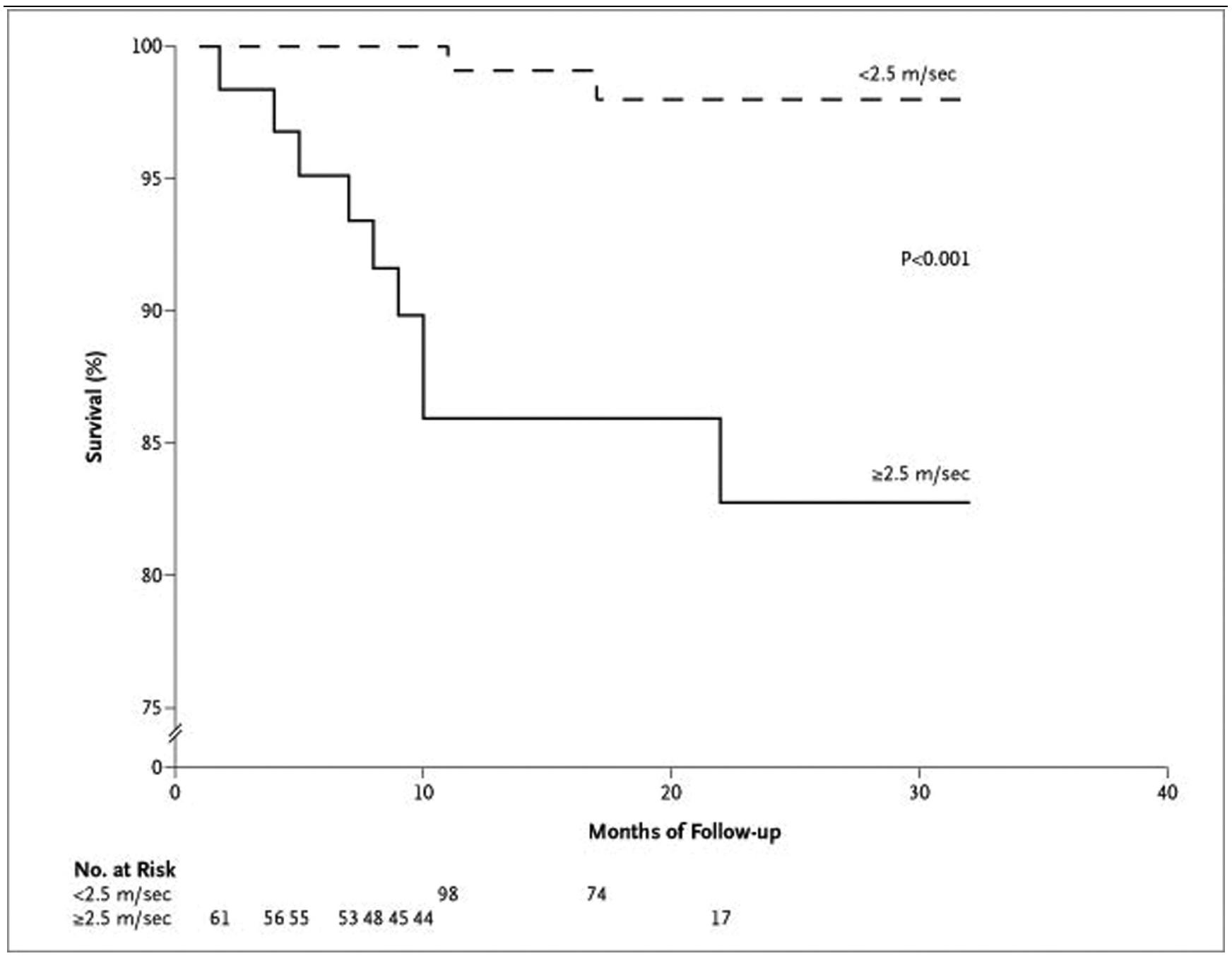

The survival rate was significantly higher among patients with a tricuspid regurgitant jet velocity of $<2.5 \mathrm{~m} / \mathrm{s}$ (indicating normal pulmonary artery pressure) than among those with a tricuspid regurgitant jet velocity of at least $2.5 \mathrm{~m} / \mathrm{s}(P<0.00 \mathrm{I})$. Because patients were enrolled over a $20-\mathrm{month}$ period, the first patients enrolled were followed for the entire time. Thus, the number of patients at risk at the time of each death is shown for both groups. (Figure and caption reproduced with permission from [8]. Copyright @ 2004 Massachusetts Medical Society. All rights reserved.

surgery should be avoided if at all possible for these patients [39].

For SCD-associated PH, most hematologists would maximize sickle cell therapy with hydroxyurea or chronic transfusions. It should be noted, however, that multiple studies did not find an association with hydroxyurea use and decreased TRV $[8,24,40,41]$. It is known that hydroxyurea decreases hemolysis and induces $\mathrm{NO}$ in endothelial cells [42] as well as improves clinical symptoms with less reported pain and fewer hospitalizations $[43,44]$. Treatment with hydroxyurea may therefore help prevent the acute episodes that exacerbate $\mathrm{PH}$ and are potentially associated with sudden death in these patients.
No prospective trials have evaluated the efficacy of transfusion therapy to decrease $\mathrm{PH}$, although chronic transfusions are known to lower plasma free hemoglobin [45] and there are a few case reports of improvement of TRV with transfusion therapy [13]. One retrospective evaluation of 55 nontransfused and 20 transfused pediatric SCD patients found significantly lower TRV in the transfused population [46].

Therapies specifically targeted at $\mathrm{PH}$ pathology include vasodilatory agents, such as phosphodiesterase- 5 inhibitors and prostanoids, as well as endothelin receptor antagonists and arginine supplementation. In a pilot study of 12 SCD patients with PH, sildenafil showed a 
decrease in TRV and pulmonary artery pressures as well as functional improvement [47]. However, a large multicenter trial treating $\mathrm{PH}$ with sildenafil was prematurely closed as there was no functional improvement and increased vaso-occlusive pain was reported in the treatment group. Therefore, the role of sildenafil therapy is still unclear. Treatment with arginine supplementation was also shown to decrease pulmonary artery pressures in ten SCD patients [48]; however, the number of pills and dosing schedule required for an effect limit the use of arginine in clinical practice. A recent study of 14 SCD patients treated with the endothelin receptor antagonist bosentan showed promising results with improved TRV and mPAP [49].

Pulmonary hypertension is now an increasingly recognized complication of hemolysis and is associated with mortality in patients with hemolytic anemia. It remains to be seen if $\mathrm{PH}$ directly results in death or simply provides a window into the severity of vasculopathy for patients with SCD. Ongoing research aims to define the most effective treatment strategies for these patients and enrolment in clinical trials is therefore of paramount importance.

\section{Abbreviations}

$\mathrm{BNP}$, brain natriuretic peptide; mPAP, mean pulmonary artery pressure; $\mathrm{NO}$, nitric oxide; $\mathrm{PH}$, pulmonary hypertension; SCD, sickle cell disease; TI, thalassemia intermedia; TM, thalassemia major; TRV, tricuspid regurgitant jet velocity.

\section{Competing interests}

The authors declare that they have no competing interests.

\section{References}

I. Vichinsky EP: Pulmonary hypertension in sickle cell disease. N Engl J Med 2004, 350:857-9.

2. Bachmeyer C, Khalil A, Kerrou K, Girot R, Gounant V: Idiopathic pulmonary arterial hypertension in a patient with pyruvate kinase deficiency and paravertebral extramedullary hematopoiesis. Ann Hematol 2009, 88:603-5.

3. Connor P, Veys P, Amrolia P, Haworth S, Ashworth M, Moledina S: Pulmonary hypertension in children with Evans syndrome. Pediatr Hematol Oncol 2008, 25:93-8.

4. Lode HN, Krings G, Schulze-Neick I, Dahmlow S, Schroeder U, Bonnet R, DaPalma J, Luck W, Strauss G, Berger F, Gaedicke G: Pulmonary hypertension in a case of Hb-Mainz hemolytic anemia. J Pediatr Hematol Oncol 2007, 29: I73-7.

5. Heller PG, Grinberg AR, Lencioni M, Molina MM, Roncoroni A): Pulmonary hypertension in paroxysmal nocturnal hemoglobinuria. Chest 1992, 102:642-3.

6. Verresen D, De Backer W, Van Meerbeeck J, Neetens I, Van Marck E, Vermeire P: Spherocytosis and pulmonary hypertension coincidental occurrence or causal relationship? Eur Respir J 1991, 4:629-3I.
7. McLaughlin VV, Archer SL, Badesch DB, Barst RJ, Farber HW, Lindner JR, Mathier MA, McGoon MD, Park MH, Rosenson RS, Rubin LJ, Tapson VF, Varga J; American College of Cardiology Foundation Task Force on Expert Consensus Documents; American Heart Association; American College of Chest Physicians; American Thoracic Society, Inc; Pulmonary Hypertension Association: ACCF/ AHA 2009 expert consensus document on pulmonary hypertension: A report of the American College of Cardiology Foundation Task Force on Expert Consensus Documents and the American Heart Association developed in collaboration with the American College of Chest Physicians; American Thoracic Society, Inc.; and the Pulmonary Hypertension Association. J Am Coll Cardiol 2009, 53:1573-619.

FI000 Factor 3.0 Recommended

Evaluated by John Augoustides 13 Nov 2009

8. Gladwin MT, Sachdev V, Jison ML, Shizukuda Y, Plehn JF, Minter K, Brown B, Coles WA, Nichols JS, Ernst I, Hunter LA, Blackwelder WC, Schechter AN, Rodgers GP, Castro O, Ognibene FP: Pulmonary hypertension as a risk factor for death in patients with sickle cell disease. N Engl J Med 2004, 350:886-95.

9. Morris CR: Mechanisms of vasculopathy in sickle cell disease and thalassemia. Hematol Am Soc Hematol Educ Program 2008: 177-85.

10. Reiter CD, Wang X, Tanus-Santos JE, Hogg N, Cannon RO 3rd, Schechter AN, Gladwin MT: Cell-free hemoglobin limits nitric oxide bioavailability in sickle-cell disease. Nat Med 2002, 8:1383-9.

II. Morris CR, Kato GJ, Poljakovic M, Wang X, Blackwelder WC, Sachdev V, Hazen SL, Vichinsky EP, Morris SM Jr, Gladwin MT: Dysregulated arginine metabolism, hemolysis-associated pulmonary hypertension, and mortality in sickle cell disease. JAMA 2005, 294:81-90.

12. Kato GJ, McGowan V, Machado RF, Little JA, Taylor Jt, Morris CR, Nichols JS, Wang $X$, Poljakovic M, Morris SM Jr, Gladwin MT: Lactate dehydrogenase as a biomarker of hemolysis-associated nitric oxide resistance, priapism, leg ulceration, pulmonary hypertension, and death in patients with sickle cell disease. Blood 2006, 107:2279-85.

FI000 Factor 3.0 Recommended

Evaluated by George Garratty 20 Apr 2007

13. Kato GJ, Onyekwere OC, Gladwin MT: Pulmonary hypertension in sickle cell disease: relevance to children. Pediatr Hematol Oncol 2007, 24:159-70

14. Hsu LL, Champion HC, Campbell-Lee SA, Bivalacqua TJ, Manci EA, Diwan BA, Schimel DM, Cochard AE, Wang X, Schechter AN, Noguchi CT, Gladwin MT: Hemolysis in sickle cell mice causes pulmonary hypertension due to global impairment in nitric oxide bioavailability. Blood 2007, 109:3088-98.

15. Minneci PC, Deans KJ, Zhi H, Yuen PS, Star RA, Banks SM, Schechter AN, Natanson C, Gladwin MT, Solomon SB: Hemolysisassociated endothelial dysfunction mediated by accelerated NO inactivation by decompartmentalized oxyhemoglobin. J Clin Invest 2005, I I 5:3409- 17.

16. Morris CR, Suh JH, Hagar W, Larkin S, Bland DA, Steinberg MH, Vichinsky EP, Shigenaga M, Ames B, Kuypers FA, Klings ES: Erythrocyte glutamine depletion, altered redox environment, and pulmonary hypertension in sickle cell disease. Blood 2008, I I I:402-10.

17. Villagra J, Shiva S, Hunter LA, Machado RF, Gladwin MT, Kato GJ: Platelet activation in patients with sickle disease, hemolysisassociated pulmonary hypertension, and nitric oxide scavenging by cell-free hemoglobin. Blood 2007, I 10:2166-72.

18. Kuypers FA: Red cell membrane lipids in hemoglobinopathies. Curr Mol Med 2008, 8:633-8.

19. Setty BN, Betal SG, Zhang J, Stuart MJ: Heme induces endothelial tissue factor expression: potential role in hemostatic activation in patients with hemolytic anemia. J Thromb Haemost 2008, 6:2202-9. 
20. Phrommintikul A, Sukonthasarn A, Kanjanavanit R, Nawarawong W: Splenectomy: a strong risk factor for pulmonary hypertension in patients with thalassaemia. Heart 2006, 92: |467-72.

21. Singer ST, Kuypers FA, Styles L, Vichinsky EP, Foote D, Rosenfeld H: Pulmonary hypertension in thalassemia: association with platelet activation and hypercoagulable state. Am J Hematol 2006, $81: 670-5$

22. De Castro LM, Jonassaint JC, Graham FL, Ashley-Koch A, Telen MJ: Pulmonary hypertension associated with sickle cell disease: clinical and laboratory endpoints and disease outcomes. Am J Hematol 2008, 83:19-25.

23. Ataga KI, Moore CG, Jones S, Olajide O, Strayhorn D, Hinderliter A, Orringer EP: Pulmonary hypertension in patients with sickle cell disease: a longitudinal study. Br J Haematol 2006, I34: I09-I5.

24. Machado RF, Anthi A, Steinberg MH, Bonds D, Sachdev V, Kato GJ, Taveira-DaSilva AM, Ballas SK, Blackwelder W, Xu X, Hunter L, Barton B, Waclawiw M, Castro O, Gladwin MT: N-terminal probrain natriuretic peptide levels and risk of death in sickle cell disease. JAMA 2006, 296:310-8.

25. Suell MN, Bezold LI, Okcu MF, Mahoney DH Jr, Shardonofsky F, Mueller BU: Increased pulmonary artery pressures among adolescents with sickle cell disease. J Pediatr Hematol Oncol 2005, 27:654-8.

26. Liem RI, Young LT, Thompson AA: Tricuspid regurgitant jet velocity is associated with hemolysis in children and young adults with sickle cell disease evaluated for pulmonary hypertension. Haematologica 2007, 92:I549-52.

27. Nelson SC, Adade BB, McDonough EA, Moquist KL, Hennessy JM: High prevalence of pulmonary hypertension in children with sickle cell disease. J Pediatr Hematol Oncol 2007, 29:334-7.

28. Dham N, Ensing G, Minniti C, Campbell A, Arteta M, Rana S, Darbari D, Nouraie M, Onyekwere O, Lasota M, Kato GJ, Gladwin MT, Castro O, Gordeuk V, Sable C: Prospective echocardiography assessment of pulmonary hypertension and its potential etiologies in children with sickle cell disease. Am J Cardiol 2009, 104:713-20.

29. Aessopos A, Farmakis D, Deftereos S, Tsironi M, Tassiopoulos S, Moyssakis I, Karagiorga M: Thalassemia heart disease: a comparative evaluation of thalassemia major and thalassemia intermedia. Chest 2005, I 27:1523-30.

30. Hagar RW, Morris CR, Vichinsky EP: Pulmonary hypertension in thalassaemia major patients with normal left ventricular systolic function. $\mathrm{Br} J$ Haematol 2006, 133:433-5.

31. Derchi G, Formisano F, Lamagna M, Galanello R, Bina P, Dessi A, Cappellini, Cassinerio E, Prossomariti L, Cinque P, Maggio A, Renda D, Cianciulli P, Cogliandro T, Piga A, Donato G, Forni GL: Pulmonary hypertension in thalassemia major: an Italian multicentric study. Poster presented at Ninth Cooley's Anemia Symposium: 2 I-24 October 2009, New York City. [http://www.nyas.org/Events/Detail. aspx?cid=9c I l e73d-2349-4cdd-8910-0d8fad I 84ced].

32. Hahalis G, Alexopoulos D, Kremastinos DT, Zoumbos NC: Heart failure in beta-thalassemia syndromes: a decade of progress. Am J Med 2005, I I 8:957-67.

33. Aessopos A, Farmakis D, Karagiorga M, Voskaridou E, Loutradi A, Hatziliami A, Joussef J, Rombos J, Loukopoulos D: Cardiac involvement in thalassemia intermedia: a multicenter study. Blood 200I, 97:34II-6.

34. Lee MT, Small T, Khan MA, Rosenzweig EB, Barst RJ, Brittenham GM: Doppler-defined pulmonary hypertension and the risk of death in children with sickle cell disease followed for a mean of three years. Br J Haematol 2009, I46:437-4I.

35. Graham JK, Mosunjac M, Hanzlick RL, Mosunjac M: Sickle cell lung disease and sudden death: a retrospective/prospective study of 2 I autopsy cases and literature review. Am J Forensic Med Pathol 2007, 28: 168-72.

36. Machado RF, Mack AK, Martyr S, Barnett C, Macarthur P, Sachdev V, Ernst I, Hunter LA, Coles WA, Nichols JP, Kato GJ, Gladwin MT: Severity of pulmonary hypertension during vaso-occlusive pain crisis and exercise in patients with sickle cell disease. $\mathrm{Br} J$ Haematol 2007, 136:319-25.

37. Atichartakarn V, Chuncharunee $S$, Chandanamattha $P$, Likittanasombat K, Aryurachai K: Correction of hypercoagulability and amelioration of pulmonary arterial hypertension by chronic blood transfusion in an asplenic hemoglobin E/beta-thalassemia patient. Blood 2004, I 03:2844-6.

38. Aessopos A, Farmakis D, Hatziliami A, Fragodimitri C, Karabatsos F, Joussef J, Mitilineou E, Diamanti-Kandaraki E, Meletis J, Karagiorga M: Cardiac status in well-treated patients with thalassemia major. Eur J Haematol 2004, 73:359-66.

39. Piomelli S: The splenectomy controversy. Ann N Y Acad Sci 2005, I054:5 I I-3.

40. Gordeuk VR, Campbell A, Rana S, Nouraie M, Niu X, Minniti CP, Sable C, Darbari D, Dham N, Onyekwere O, Ammosova T, Nekhai S, Kato GJ, Gladwin MT, Castro OL: Relationship of erythropoietin, fetal hemoglobin, and hydroxyurea treatment to tricuspid regurgitation velocity in children with sickle cell disease. Blood 2009, I | 4:4639-44.

4I. Minniti CP, Sable C, Campbell A, Rana S, Ensing G, Dham N, Onyekwere O, Nouraie M, Kato GJ, Gladwin MT, Castro OL, Gordeuk VR: Elevated tricuspid regurgitant jet velocity in children and adolescents with sickle cell disease: association with hemolysis and hemoglobin oxygen desaturation. Haematologica 2009, 94:340-7.

42. Goldberg MA, Brugnara C, Dover GJ, Schapira L, Charache S, Bunn HF: Treatment of sickle cell anemia with hydroxyurea and erythropoietin. N Engl J Med 1990, 323:366-72.

43. Strouse JJ, Lanzkron S, Beach MC, Haywood C, Park H, Witkop C, Wilson RF, Bass EB, Segal JB: Hydroxyurea for sickle cell disease: a systematic review for efficacy and toxicity in children. Pediatrics 2008, I 22: I 332-42.

44. Lanzkron S, Strouse JJ, Wilson R, Beach MC, Haywood C, Park H, Witkop C, Bass EB, Segal JB: Systematic review: Hydroxyurea for the treatment of adults with sickle cell disease. Ann Intern Med 2008, I 48:939-55.

45. Lezcano NE, Odo N, Kutlar A, Brambilla D, Adams RJ: Regular transfusion lowers plasma free hemoglobin in children with sickle-cell disease at risk for stroke. Stroke 2006, 37:|424-6.

46. Joyce K, Sable C, Martin B, Minniti C: Pulmonary artery hypertension in children with sickle cell disease: is chronic transfusion protective? Blood 2006, 108:356a.

47. Machado RF, Martyr S, Kato GJ, Barst RJ, Anthi A, Robinson MR, Hunter L, Coles W, Nichols J, Hunter C, Sachdev V, Castro O, Gladwin MT: Sildenafil therapy in patients with sickle cell disease and pulmonary hypertension. $\mathrm{Br} J$ Haematol 2005, 130:445-53.

48. Morris CR, Morris SM Jr, Hagar W, Van Warmerdam J, Claster S, Kepka-Lenhart D, Machado L, Kuypers FA, Vichinsky EP: Arginine therapy: a new treatment for pulmonary hypertension in sickle cell disease? Am J Respir Crit Care Med 2003, I 68:63-9.

49. Minniti CP, Machado RF, Coles WA, Sachdev V, Gladwin MT, Kato G]: Endothelin receptor antagonists for pulmonary hypertension in adult patients with sickle cell disease. $\mathrm{Br} J$ Haematol 2009, 147:737-43. 